\title{
21. PRELIMINARY PALEOMAGNETIC RESULTS, BASALTS, LEG 19
}

John Whitney and R. T. Merrill, University of Washington, Seattle, Wash.

\section{EXPERIMENTAL PROCEDURES}

Cylindrical samples approximately one inch long and one inch in diameter were taken from basalt recovered at Sites 183, 191 and 192. Remanent magnetizations were measured with a Schonsted slow-spinner magnetometer, AF demagnetizations were made using a four-axis tumbler system and a 60-hertz alternating field, thermal demagnetization was conducted in a nonmagnetic space $( \pm 50 \gamma)$, and strong field versus temperature measurements (J-T) were made in a 1000 oe field in a Princeton vibrating sample magnetometer. In addition, polished sections were examined with a reflecting microscope.

\section{RESULTS}

Because of unknown amounts of core rotation during drilling, only inclinations are reported. These are measured with respect to the present horizontal (negative upward) assuming vertical boreholes. Intensities of NRM were reduced by roughly one-half after $\mathrm{AF}$ demagnetization in peak fields of 100 to 200 oe. Inclinations for two samples from every core section of basalt were obtained by thermal demagnetization (uppermost inclination given for each section in Table 1) and by AF demagnetization. Inclination data for samples from the same core section are reasonably consistent, but large variations exist in data for samples from different sections. The results are summarized in Table 1.

J-T measurements of three samples from Site 192 made in helium and air produced irreversible heating and cooling curves very similar to those found for titanomaghemite (Ozima and Ozima, 1971). A new phase appears near $400^{\circ} \mathrm{C}$. as indicated by an increase in J, on heating in air or helium. The Curie point of this new phase, obtained from the cooling curve, was near $525^{\circ} \mathrm{C}$. Reflecting microscope observations indicated the presence of small titanomagnetite grains, some of which showed signs of lowtemperature oxidation to titanomaghemite and/or unmixing to hemoilmenite and a more iron-rich titanomagnetite.

\section{PRELIMINARY CONCLUSIONS}

The variation in the inclinations at Site 192, and perhaps at Site 191, is too large to attribute to secular variation.
TABLE 1

Summary of Magnetic Data

\begin{tabular}{|c|c|c|c|}
\hline $\begin{array}{c}\text { Sample } \\
\text { Designation }\end{array}$ & $\begin{array}{c}\text { Depth } \\
(\mathrm{cm})\end{array}$ & $\begin{array}{c}\text { NRM } \\
\text { Intensity } \\
\left(\mathrm{X} 10^{3} \mathrm{emu} / \mathrm{cc}\right)\end{array}$ & $\begin{array}{l}\text { Inclination } \\
\text { (degrees) }\end{array}$ \\
\hline $192 A-6-3$ & 25 & $\begin{array}{l}5 \\
5\end{array}$ & $\begin{array}{l}+6 \\
+4\end{array}$ \\
\hline $192 A-6-3$ & 72 & 12 & $\begin{array}{l}+8 \\
+9\end{array}$ \\
\hline $192 A-5-3$ & 139 & $\begin{array}{l}3 \\
3\end{array}$ & $\begin{array}{l}+34 \\
+28\end{array}$ \\
\hline $192 A-5-2$ & 21 & $\begin{array}{l}5 \\
6\end{array}$ & $\begin{array}{l}-48 \\
-44\end{array}$ \\
\hline $192 A-5-6$ & 1 & $\begin{array}{l}3 \\
2\end{array}$ & $\begin{array}{l}+56 \\
+58\end{array}$ \\
\hline $191-16-1$ & 144 & $\begin{array}{l}2 \\
1\end{array}$ & $\begin{array}{l}+40 \\
+32\end{array}$ \\
\hline $191-15(\mathrm{CC})$ & - & $\begin{array}{l}6 \\
5\end{array}$ & $\begin{array}{r}+2 \\
-11\end{array}$ \\
\hline $191-16-1$ & 70 & 1 & $\begin{array}{l}\text { Unreliable data: large } \\
\text { change in inclination on } \\
\text { every step of } \mathrm{AF} \\
\text { demagnetization }\end{array}$ \\
\hline $183-39-1$ & 148 & $\begin{array}{l}3 \\
2\end{array}$ & $\begin{array}{l}+13 \\
+13\end{array}$ \\
\hline
\end{tabular}

Speculations as to why such a large variation in inclinations exists include low-temperature oxidation effects, tectonic effects, etc. In any case, the variation in inclinations is too large to allow speculation on paleo-plate motions.

\section{ACKNOWLEDGMENTS}

We thank S. Levi for some helpful discussions. This work was partially supported by National Science Foundation grant GA-27570.

\section{REFERENCE}

Ozima, Minoru, and Ozima, Mituko, 1971. Characteristic thermomagnetic curve in submarine basalts. J. Geophys. Res. 76, 2051. 